\title{
Assessment of School Principals' Reassignment Process
}

\author{
Şenay Sezgin-Nartgün ${ }^{1, *}$, Serkan Ekinci ${ }^{2}$ \\ ${ }^{1}$ Faculty of Education, Abant Izzet Baysal University, Turkey \\ ${ }^{2}$ Department of Educational Administration and Supervision, Abant Izzet Baysal University, Turkey
}

Copyright $\mathrm{O} 2016$ by authors, all rights reserved. Authors agree that this article remains permanently open access under the terms of the Creative Commons Attribution License 4.0 International License

\begin{abstract}
This study aimed to identify administrators' views related to the assessment of school principals' reassignment in educational organizations. The study utilized qualitative research design and the study group composed of 8 school administrators selected via simple sampling who were employed in the Bolu central district in 2014-2015 academic year. Data were collected with the help of semi-structured interview form and analyzed with content and descriptive analyses. According to research results, administrators believed that written exams should be utilized, the exam used in administrator selection has low validity and reliability values and the oral exam is not fair.
\end{abstract}

Keywords School, Reassignment, Administrators, Teacher

\section{Introduction}

It is an undeniable fact that educated individuals significantly contribute to the public space in the transfer of knowledge-age related endeavors. In this context, modern societies strive to ensure the effectiveness, productivity and quality of education in general and schools in particular to actualize integration between the state and the citizens. Expectations from education differ based on requirements to use human and material resources effectively and productively and the need is increasing day by day for well-equipped and well trained teachers and administrators who are open to continuous development.

Schools that provide training and education have an impact area that can holistically affect social life. Therefore schools are not similar to other public organizations in terms of their operations [1]. Due to their positions, school administrators interact with different segments of society which have various expectations and requests from administrators [2]. In this respect, tasks and responsibilities of administrators who are obliged to ensure the continuity and development of schools have immensely changed [3].

As an authority that retains the legal power in the organization, a school administrator is responsible from ensuring that the school realizes its objectives, conserve its structure, protects its climate and develop its qualities [3]. Also, preparing educational environments and motivating teachers are priorities. Therefore, assigning qualified school administrators is a crucial variable that can affect schools' functionality.

Schools that have important responsibilities in training the human resources should be well managed in order to be efficient and successful [4]. In this respect, educational administration includes critical elements that will provide effective functioning of the educational system. Effective or ineffective school management will directly affect student success [5] and therefore responsibility of efficient school administrators depend on many factors as well as awareness of and ability to define their roles [6]. More clearly, when school administrators, who are responsible from the management of schools first hand, receive scientific and quality education, it will be easier to facilitate the realization of school objectives at desired levels. Development of a positive climate will be hindered when school administrators only care for material elements and neglect the human element [7]. School administrators play a major role in determining direction for successful schools. However, there is no sufficient knowledge about the best methods promoting and preparing qualified candidates [8]. Besides, it is reported that there are no school administrators with sufficient competence to manage the budget and expenses of schools [9].

School administrators should be assigned according to scientific criteria [10] because they are expected to have the capacity and competency to handle with legal issues about school management, educational leadership and human resource management [11].

Especially modern societies regard the task of identification and training of school administrators very seriously to ensure efficiency at schools, to provide a school climate and culture that allows for active learning and to have schools undertake social tasks and responsibilities [12]. To achieve significant advances in education, it is important to have school administrators who take initiative, make changes and display leadership but not the ones only obeying the rules [13]. So practices are necessary to provide 
capacity building so that all elements in the school system work more effectively and productively and these practices should involve school administrators first (Thoonen, Sleegers, Oort and Peetsma, 2012: Cited in: [14].

Although pre-service and/or in-service trainings provided for school administrators in the field of administration are crucial to allow them meet the demands of new tasks and responsibilities, approaches used by countries in providing managerial training and the significance attached to those trainings while assigning school administrators are not the same [14] although there are some differences in training of school administrators their being professionals is a commonly cared and important issue for all the countries [15]. National Education central and district organizations were reorganized with the Law on Unification of Education (Tevhid-i Tedrisat Kanunu) dated 3 March 1924. While there are suggestions to train educational administrators for their posts, it is not possible to discuss the existence of any practices in this regard [16]. Unfortunately, let alone having set policies regarding the training provided for school administrators in the field of administration, even the regulation on administrator assignment continuously changes (Date- Issue of Official Gazette: 27.01.2016-29606, 06.10.2015-29494, 04.08.2013-28728, 28.02.2013-28573, 21.07.2012-28360, $09.08 .2011-28020, \quad 15.05 .2010-27582$, 13.08.2009-27318, 24.04. 2008-26856, 15.10.2008-27025 13.04.2007-26492, 11.01.2004-25343, 30.04.1999-23681, 07.06.1993-21600). Since it is not possible to ensure continuity of practices in the selection and assignment of school administrators, uncertainties emerge and sometimes school administrators are even assigned in the middle of the school terms instead of at the beginning of the academic year. This practice of course negatively affects school efficiency and student and teacher performances. Also, since these regulations are not handled with pre-service and in-service training, counseling, guidance and competence, the process does not come to a conclusion [17]. Advances brought forth with the knowledge age have enforced changes in educational systems and therefore, it has become necessary to train school administrators in line with these changes so that transformations do not hinder achievement [18]. School administrators are also expected to approach these trainings as a way of life.

Since the main goal of educational administration is to support education and training [19], it is not sufficient for the administrators in educational organizations only to deal with routine managerial tasks and they are expected to work in cooperation with all other employees at the school and have awareness about educational processes as well [1].

The report of Mehtap Project published in 1962 emphasized once again that educational administration required a unique expertise and made suggestions to train administrators in undergraduate departments established for this purpose. In this context, Ankara University Faculty of Educational Sciences was opened and other universities followed suit. Undergraduate programs in faculties of education to train educational administrators in some of the universities in Turkey were closed down in the context of restructuring with the communication of the Council of Higher Education dated and numbered 06.11.1997/B $30.0 .000 .0 .01,534-22449$ and master's programs with or without thesis were particularly popularized [20]. However, this new structuring is not taken into consideration during the selection of the administrators, there are no legal requirements for school administrators to take leadership/administrative training in order to be assigned as school administrators and it is not presented as a prerequisite for selection exams. Moreover, school administrators securing their posts thanks to political power and links do not try to have a master or doctoral degree which is a challenging process [21]. The basic requirement to be assigned as a school administrator is being a teacher and therefore school administrators are selected from among teachers while they may be asked to teach again when necessary without considering whether this will affect and hinder the educational process. Also, educational administration is not a field of management with qualifications and competences and teachers with political and bureaucratic support can be assigned as administrators without considering their qualifications, competences and educational status [4]. In other words, approaches which focus on administrators' closeness to the political power and unions result in ignoring school administrators' qualifications, merits and competences in selection and assignment.

It is crucial that people with the required skills manages educational organizations to realize the planned goals (Cunningham and Cordeiro, 2000: Cited in: [22]. It should be comprehended that administrators should have serious educational endeavors and academic training to ensure that administration is perceived as a respectable profession and qualifications and merit should be sought in all types of assignments and advancements [16]. Hence, while training school administrators is necessary to regard administration as a professional occupation in Turkey [24], the biggest problem facing the Turkish National Education System to regard administration posts from different perspectives is the fact that teaching and administration are interconnected and interwoven [25]. MoNE does not associate school administration with professionalism but regards it as a task that all teachers can undertake and therefore no efforts are made to train school administrators for their duties and in fact, it is not even in MoNE's agenda. Hence, the problems related to assigning administrators increasingly continue [5]. Demands of teachers who adopt school goals as their own and significantly contribute to organizational achievement will be considered as threats at schools where the real problem is actually caused by administrators and these teachers will be regarded as individuals who stir trouble and all these factors will immensely affect school quality.

\subsection{Purpose of the Study}

This study aimed to identify school administrators' views 
regarding the evaluation of reassignment process for school administrators. In this context, the study sought answers to the following questions:

1. What are the participants' views on the selection process of school administrators?

2. What are the participants' views on the validity and reliability of exams done during the selection process?

3. What are the participants' views on how the selection process should be?

\section{Materials and Methods}

\subsection{Research Model}

Research data were obtained with qualitative research methods and phenomenologic design, one of the qualitative research designs, was used in the study. Phenomenologic design focuses on concepts of which people are aware but about which they are not informed in depth or in detail and allows the researcher to investigate the concepts that are not completely foreign but not fully comprehended either [26].

\subsection{Study Group}

Since data sources in phenomenologic studies are individuals or groups that experience or reflect the investigated concept [26], study group for the present study was composed of school administrators employed in Bolu central district in 2014-2015 academic year. While determining study group, chain sampling method was utilized. Participants helped the researchers by directing them to new participants. The aim of choosing this sampling method is that participants know each other and they can direct the researcher to the knowledgeable people about the issue. This also allows the researchers to obtain data in depth (27). School administrators in primary and secondary schools that were easier to reach were contacted and interviews were undertaken with voluntary school administrators with the help of semi-structured interview form. 8 voluntary school administrators were interviewed to ensure trust between the researcher and the participant. Personal information was kept confidential. The reason why more participants were not applied was that they repeated the same views. On the other hand, obtaining data in depth is more important than reaching more participants in qualitative studies. Therefore, expertise and experience of the sample is invaluable. In qualitative studies, the validity and significance depend on not the size of the sample but the participants' expertise and the researchers' observational and analytic competencies (27).

\subsection{Data Collection Tool}

Semi-structured interview form was developed in the study to present an in-depth description of school administrators' views about reassignment process focusing on what they thought and why they thought so. Literature review was undertaken for this purpose to prepare the questions used in the interview and questions were decided with the help of the literature review. 2 instructors from Abant Izzet Baysal University, Faculty of Education, Educational Administration and Supervision and 2 Turkish teachers employed in Bolu central schools were contacted for their views in order to finalize the questions included in the semi-structured interview form. In this context, the form was piloted on four school administrators to assess intelligibility. Semi-structured interview form finalized.

\subsection{Data Analysis and Interpretation}

Content analysis technique was used in analyzing the data obtained in the framework of the study. The main goal in content analysis is to arrive at the concepts and relationships that can explain the data. First, data need to be conceptualized and then rearranged logically according to observed concepts [26]. With this purpose in mind, data were examined before content analysis and concepts were separated meaningfully and data that conceptually formed a meaningful entirety were combined to find related frequency. The repetitions points to frequency not to the number of individuals. Since analysis focused on questions, additional themes were not generated.

In terms of validity, striking participant views were directly quoted. In terms of reliability, actions taken during the study were explained in method section. Also, two researchers examined and analyzed the data during the study. Results were compared and points that were agreed upon were presented to the reader. Consensus ratio was found to be $98 \%$.

\section{Findings}

\subsection{Findings related to Selection Process during Administration Assignment}

Table 1. Frequency Distributions of Administrator Views regarding the Selection Process

\begin{tabular}{|c|c|}
\hline Views & (f) \\
\hline Exam is subjective & 6 \\
\hline Oral interview is not fair & 4 \\
\hline Union memberships and political decisions & 3 \\
\hline Need for a written exam (objective criteria) & 3 \\
\hline Favoritism & 2 \\
\hline Insufficient Evaluation Criteria (Annex-1) & 2 \\
\hline The fact that selected administrators are unsuccessful & 1 \\
\hline Oral interview is not regarded as ethical & \\
\hline
\end{tabular}

Examination of Table 1 which presents administrator 
views regarding the selection process of administrators shows that the most frequently expressed views were the subjective nature of the exam ( $\mathrm{f}=6)$, lack of fairness in the oral interview $(\mathrm{f}=5)$ and the effect of union membership and political decisions on school administrator assignment $(\mathrm{f}=4)$. A2 reports that "Evaluation is based on subjective, biased and political views. Qualifications and foundations of career are ignored and personal thoughts and union memberships are taken as reference and evaluation criteria" whereas $\mathrm{A} 3$ and $\mathrm{A} 8$ also report similar views.

When selection process is evaluated in general according to administrator views, it was found that evaluation was subjective, the oral interview was not fair, union memberships and political decisions played a role in the selection, favoritism was experienced therefore the process was not ethical, the criteria included in Annex-1 were not sufficient, there was a need for a written exam and therefore, there was a possibility of failure related to current assignments.

\subsection{Findings Related to the Respectfulness of Administrator Assignments According to Gender Variable}

Table 2. Frequency Distributions of Administrator Views regarding the Respectfulness of Administrator Assignments

\begin{tabular}{|c|c|}
\hline Views & (f) \\
\hline Need for a more respected/fair written exam & 7 \\
\hline Lack of objectivity in oral interview & 6 \\
\hline $\begin{array}{c}\text { Favoritism, effects of political views and } \\
\text { discrimination based on union membership }\end{array}$ & 5 \\
\hline Necessity for establishing criteria & 2 \\
\hline Leadership skills & 2 \\
\hline Necessity for experience & 2 \\
\hline Necessity for time & 1 \\
\hline Necessity to change the system of examination & \\
\hline
\end{tabular}

Table 2 presents that school administrators most frequently expressed the following views about respectfulness of assignments: necessity for a more respectful/fair written exam ( $\mathrm{f}=7)$, lack of objectivity in oral interview ( $\mathrm{f}=6)$ and favoritism, effects of political views and discrimination based on union membership $(\mathrm{f}=5)$. Some administrators reported that "Although there are some problems in the evaluations done via central examinations, it can be said that they are much more objective. Although the exam is believed to measure a cognitive skill, when multiple-choice exams are used the strength of the criteria used in evaluation increases and it provides an equal and fair assessment" (A2). Views similar to those of A2 were expressed by A3, A8 and A5. A5 also added that "Probability of acceptance by teachers is higher for the administrator who is assigned based exam score..".
Administrator views related to respectfulness of administrator assignments pointed that written exams were more respectful/fair, oral interview was not objective, favoritism was experienced, assignments were done based on political views union membership, there was a need for inclusive criteria, leadership skills should be taken as a criteria, there was a need for experience in administration and that it was necessary to change the exam system.

\subsection{Findings Related to Negative Experiences during Administrators' Assignment Process}

Table 3. Frequency Distributions of Administrator Views regarding Negative Experiences during Administrators' Assignment Process

\begin{tabular}{|c|c|}
\hline Views & (f) \\
\hline Non-objective Assignments & 4 \\
\hline Subjective Evaluation & 2 \\
\hline Right to Object & 1 \\
\hline Regulation & 1 \\
\hline Error in Timing & 1 \\
\hline
\end{tabular}

According to Table 3, school administrators most frequently expressed the following views about the negative experiences during the assignment process: non-objective assignments ( $\mathrm{f}=4)$ and subjective evaluation $(\mathrm{f}=2)$. Administrators expressed the following views:

"...It will and has resulted in an assignment process that is unfair..." (A1).

"...I don't believe that oral interviews in Turkey are objective...” (A3).

"...The people who came out of the interview room complained about the questions. Some said that questions were irrelevant such as what are the forests in Bolu etc..." (A8).

However, different from the other administrator views, A5 stated that legal procedures could be used against the negative experiences during the process: "...If there are any complaints that the process does not work effectively, right to legal remedies/right to object is given in accordance with the legislation since the legislation provides this right...".

Regarding the administrator views about the negative experiences during the assignment process, A7 stated that "...Only the time planning was erroneous. Administrators were assigned during the school term or the previous administrators were obliged to start teaching again during the same period...". When school administrators' views regarding the negative experiences during the assignment process were considered holistically, it was observed that administrators reported non-objective assignments and subjective evaluation. On the other hand, one administrator view pointed to a different aspect by stating that time planning was erroneous during the assignment period and this error negatively affected the educational process. 


\subsection{Findings regarding the Validity and Reliability of the Administrator Assignment Exam}

Table 4 presents that school administrators most frequently expressed the following views about the validity and reliability of the oral exam: the oral exam was subjective $(\mathrm{f}=5)$ and had low validity and reliability $(\mathrm{f}=4)$.

Table 4. Frequency Distributions of Administrator Views regarding the Reliability and Validity of the Exam

\begin{tabular}{|c|c|}
\hline Views & (f) \\
\hline Oral exam is subjective & 5 \\
\hline Low validity and reliability & 4 \\
\hline Necessity to record the oral exam & 1 \\
\hline Lack of unbiased, equal and fair evaluation & 1 \\
\hline Exam commission is competent & 2 \\
\hline Oral exam standard measurement tool & \\
\hline
\end{tabular}

Some of the administrator views are presented below:

"... Since the answers provided to the questions were oral in their nature, evaluation is based on the individuals who will assess the answers and complete fairness is never possible when the reliability and validity criteria are based solely on people..." (A1).

"The commission should not depend on the political authority. Commission should include individuals from all unions, the repapered questions should be examined in terms of reliability and validity and levels of questions should be equal ..."(A8).

Regarding the validity and reliability of the oral exam used in administrator assignments, some administrators provided the following suggestions to ensure reliability and validity: "Interviews are possible but they can be used to make decisions between candidates whose objective and measurable scores are close to each other in..."(A3), "There will be no problems as long as interview includes questions about the content area and scoring is identified with a scoring rubric that accompany the questions..."(A4). On the other hand, one administrator reported that the reliability and validity of the exam was sufficient since "Oral interview commission was composed of administrators with sufficient competence. Also, practices such as selecting the interview questions by drawing lots and having the answer also in written form were nice..." (A7).

When school administrators' views regarding the reliability and validity of the oral interview during the assignment process were considered as a whole, it was found that the exam was found to be subjective and had low reliability and validity, it was necessary to record the exam to ensure objectivity, there were concerns related to lack of unbiased, equal and fair assessment and there was a need to develop and utilize an oral exam standard assessment tool. However, there was one administrator who did not share the same views and believed that the exam commission was competent and assessments were objective.

\subsection{Findings Related to Suggestions for Assigning Administrators}

Table 5. Frequency Distributions of Administrator Views Regarding Suggestions for Assigning Administrators

\begin{tabular}{|c|c|}
\hline Views & (f) \\
\hline Written exam & 3 \\
\hline Administrative experience & 2 \\
\hline Annex-1 & 2 \\
\hline Priority for administrators with graduate degrees & 2 \\
\hline The exam should be diversified & 3 \\
\hline $\begin{array}{c}\text { The effect of the oral exam on the result should be } \\
\text { less }\end{array}$ & 2 \\
\hline
\end{tabular}

Table 5 presents that school administrators most frequently expressed the following views about their suggestions for assigning administrators: written exam $(\mathrm{f}=3)$, administrative experience $(\mathrm{f}=2)$, Annex-1 $(\mathrm{f}=2)$, priority for administrators with graduate degrees $(f=2)$, necessity to diversify the exam $(\mathrm{f}=3)$, keeping the share of the oral exam lower $(f=2)$. Some of the interesting views related to this item are as follows: A4 stated that "School principals should be selected from among individuals with a certain degree of seniority or from among assistant principals following a written exam in which the candidates obtain a specific score. Later, additional scoring is used for selection. System of additional scoring includes periods of prior administrative duties, level of education, technological skills, periods of in-service training and seniority. At the end of the process, interview can be used as the least determinant criteria (5\%)...". A5 similarly mentioned that "First of all, candidates should go through pre-selection with a centralized exam and the individuals who cannot go over a specific threshold should be eliminated, specific documents and certificates should be included in scoring with the help of Annex-1 and an interview should be given". Additionally, A6 reported that "...I believe that - if that can be put into practice- establishing a National Education Academy and training future administrators here would be more beneficial"

Views related to suggestions for assigning administrators were found to focus on the necessity for a written exam. It was also stated that there was a need for administrative experience; graduate education should be regarded as a priority in candidates, only written or inly oral exams were not sufficient for evaluation, share of the oral exam should be kept lower in the general score and the exam should be diversified in nature.

\section{Result, Discussion and Suggestion}

This study aimed to identify school principals' views related to school administrators' reassignment process. Based on the results obtained in the study, it was generally observed in the selection process that evaluations were 
subjective, oral exam was not fair, union memberships and political decisions were effective, favoritism was possible therefore it was not considered to be ethical, criteria presented in Annex-1 were not sufficient and therefore there was a probability for failure in the long run. These findings were found to be parallel to the findings presented in studies in literature. In this context, studies by Demirtaş and Özer [6] and Aktepe [28] also pointed that exam was not solely sufficient in itself and it was suggested that individuals with at least a master's degree in the field of administration who have high performance and achievement in related posts and who perform high level leadership and human relations are suitable for administrative posts. Similarly, results of Özmen and Kömürlü's [29] study showed that selection exam should still be continued.

Administrator views related to respectfulness of assignment showed that written exam was more respected/fair and the oral exam was not objective, favoritism was experienced, assignments were done under the effect of political views and union memberships, there was a need for inclusive criteria, leadership skills could be taken as criteria, there was a need for experience in administration and the exam system should change. These findings in the current study correspond to Demirtaş and Özer's [6] finding that school principals regard the effect of pressure groups (union, political party etc.) negatively during the assignment of school principals.

Administrator views related to negative experiences during the assignment of school principals as a whole showed that non-objective assignments were done and the evaluation was not subjective. On the other hand, one of the administrators pointed to a different perspective and stated that time planning was erroneous during the assignments and that negatively affected the educational process. In their study, Türkmenoğlu and Tuncer [30] found that the majority of school administrators believed the written exam was more objective, it allowed for fair scoring and oral exam may hinder some individuals to get access to the posts they deserved and that they were concerned about this new type of assignment process and they believed this practice may create uncertainty and chaos.

Administrator views related to reliability and validity of the exam during the assignment of school principals showed in general that the exam was subjective and had low reliability and validity, there was a need to record the process to ensure its subjectivity, there were concerns about fair and equal evaluation and an oral exam standard measurement tool should be developed to prevent bias and favoritism. However, there was an administrator view that did not agree with the common view and that stated the exam commission was competent and evaluation was objective. These findings regarding the reliability and validity of the exam used in assigning administrators correspond to the findings of Özmen and Kömürlü [29] which reported school principals' belief that selection and assignment process should be transparent and based on performance. Gülşen and Dayığlu [31] also found that using objective and concrete data as criteria during reassignment for educational administration posts will prevent instances of favoritism.

Administrator views about suggestions for assignment process emphasized the need for a written exam. Also, the need for experience in administration, graduate degrees should be regarded as a priority in candidates, insufficiency of only written or only oral exams, the need to keep the share of oral exam lower and the need to diversify the exam were also mentioned. Özmen and Kömürlü's [29] study reported that candidates for principals should be selected from among successful school administrators and it is necessary to have at least two-year master's degree or go through two-year training in the field of administration. Demirtaş and Özer [6] also stated that gaining experience in administration is important starting with assistant principal posts since there are cases when the administrators who pass the exam may not have experience in administration.

Competences and qualifications of administrators who shoulder responsibility at the highest level in realizing organizational goals play significant roles in guiding employees towards organizational goals by affecting them [32]. Having individuals with the required skills at administrative posts is crucial to reach the planned objectives (Cunningham and Cordeiro, 2000: Cited in: [22].

Thereby, they are expected to have the competency and capacity to handle with legal issues on school administration, curriculum and educational leadership, human resource management (11). While it was stated that administrators should have master's or doctorate degrees in the field of educational administration [1] there are no legal obligations in Turkey to obtain administrative training to be assigned to educational administration or school administration posts and the existence of such a training has a small contribution to the overall assessment.

In this context, previous studies focusing on teacher views found that school administrators benefited from scientific studies at low levels [3], school principals have significant deficiencies in problem solving skills [33] and they have low levels of listening, human relations, conflict management, motivation and personal adaptation skills [34]. However, a qualified school administrator should form communication networks, cooperation and partnerships. He should try to use assessments depending on accountability and evidence [35].

Results of the current study emphasize the significance of administrator selection for managing schools with awareness and effectiveness. Schools are not very simple organizations that can be managed only with laws and regulations. Teachers and students at schools may be affected by various external pressures. It should be kept in mind that problems generated by these pressures cannot be solved by assigning administrators who are not objective or fair, also a certain level of experience cannot be gained without obtaining some type of management education and intellectual capacity alone is not sufficient to overcome the negative conditions that can affect the realization of goals related to school, teachers and students. All these not only hinder goal realization but also affect the relationships between other 
systems and the school which is a social system itself.

Accordingly, future achievements of societies are dependent on organizational success achieved by schools. Administrator selection is one of the important topics that need to be addressed since administrators affect teachers, students and parents with their behaviors that center on continuous development and self-renewal as a principle and goal. Therefore, assigning administrators without the use of multiple phases of evaluation, by using social relationship networks, long term affiliations or closeness to certain sects will neither benefit the educational system in the future nor will create loss of resources.

\section{Suggestions}

1. Qualifications, one of the human resources basic principles, should be used in selection during administrator assignments.

2. A structured measurement tool should be developed by increasing the reliability and validity of oral measurement tool.

3. Arrangements should be made to encourage school administrators to have graduate education in the field of educational administration and candidates with training in this field should have increased weights in evaluation.

4. In oral exam, candidates should be given a case and their capacity to administer a school should be determined.

5. Assignment and assessment criteria for school administrators should be in line with universal principles and standards (ISLLC etc.).

\section{REFERENCES}

[1] Şişman, M. ve Turan, S. (2004). Eğitim ve Okul Yönetimi. Y. Özden (ed.), Eğitim ve Okul Yöneticiliği, 99-146. Ankara: Pegem A Yayıncılık.

[2] Erdem, A.R. (2015). Eğitim yönetimi etiği ve eğitim yönetiminde etik liderliğin kritiği. Akademik Sosyal Araştırmalar Dergisi. 3 (10), 1-15.

[3] Balcı, İ ve Kavak, Y. (2014). İlköğretim okulu yöneticilerinin bilimsel çalışmalardan yararlanma düzeylerine ilișkin yönetici ve öğretmen görüşleri. Eğitim Bilimleri Dergisi, 39, $55-70$.

[4] Aslanargun, E. (2011). Türkiye'de okul yönetimi ve atama yönetmelikleri. e-Journal of New World Sciences Academy Education Sciences, 6, (4), 2646-2659.

[5] Gedikoğlu,T. (2015). Liderlik ve Okul yönetimi. Anı yayıncılı. Ankara.

[6] Demirtaş, H. ve Özer, N. (2014). Okul müdürlerinin bakış açısıyla okul müdürlüğü. Kastamonu Ĕgitim Dergisi, 22 (1), $1-24$

[7] Can, N. (2007). İlköğretim okulu yöneticisinin bir öğretim lideri olarak yeni öğretim programlarının geliștirilmesi ve uygulanmasındaki yeterliliği. Eğitimde Kuram ve Uygulama $3(2), 228-244$.

[8] Darling-Hammond, L., LaPointe, M., Meyerson, D., ve Orr, M. (2007). Preparing school leaders for a changing world: Executive summary. Stanford, CA: Stanford University, Stanford Educational Leadership Institute.

[9] Özer, N., Demırtaş, H. ve Ateş, F. (2015). Okulların mali durumlarına ve bütçe yönetiminde yaşanan sorunlara ilişkin müdür görüșleri. e-International Journal of Educational Research, 6 (1), 17-39.

[10] Bursalığlu, Z. (2011). Okul yönetiminde yeni yap1 ve davranış. Ankara: Pegem Akademi.

[11] Ng, S.W and Szeto, S.E. (2016). Preparing school leaders: The professional development needs of newly appointed principals Educational Management Administration \& Leadership . 44 (4), 540-557.

[12] Memduhoğlu, H. B. (2007). Türk eğitim sisteminde okulların yönetimi ve okul yöneticilerinin yetiştirilmesi sorunsalı. Milli Ĕgitim Dergisi, 176, 86-97.

[13] Brinia, V. ve Papantoniou , E. (2016). High school principals as leaders: styles and sources of Power. International Journal of Educational Management, Vol. 30 Iss 4 pp. 520 - 535.

[14] Balkar, B. ve Kalman, M. (2015). Okul iklimi, öğretimsel liderlik ve yönetsel liderlik değişkenlerinin okul yöneticiliğine atama yaklaşımları açısından ayırt edicilik düzeyi Elektronik Sosyal Bilimler Dergisi. 14(54), 141-159.

[15] Maya, İ. (2016). Okul müdürlerinin yetiştirilmesinde dünyadan örnek programlar Aypay, A. (Ed.), Türkiye'de eğitim yöneticiliği ve maarif müfettişliği: seçme, atama ve yetiştirme (147-172). Ankara: Pegem Akademi.

[16] Cemaloğlu, N. (2005). Türkiye'de okul yöneticisi yetiştirme ve istihdamı: Varolan durum, gelecekteki olası gelișmeler ve sorunlar. Gazi Eğitim Fakültesi Dergisi. 2, 249-274.

[17] Aypay, A (2016). Eğitim yönetimi ve denetimi alanının durumu ve geleceği okul ve özellikleri. Aypay, A. (Ed.), Türkiye'de eğitim yöneticiliği ve maarif müfettişliği: seçme, atama ve yetiștirme (1-19). Ankara: Pegem Akademi.

[18] Çelikten, M. (2001). Okul yöneticilerinin problem çözme becerileri. Kuram ve Uygulamada Eğitim Yönetimi, 7(3), 297-309.

[19] Özdemir, S. (2013). Eğitim Yönetiminde Kuram ve Uygulama. Özdemir, S. (Ed.), eğitim yönetiminin alanı ve kapsamı, 1-8. Ankara: Pegem A Yayıncilık.

[20] Şişman, M. ve Turan, S. (2002). Dünyada eğitim ve yöneticilerinin yetiştirilmesine ilişkin başlıca yönelimler ve türkiye için çıkarılabilecek bazı sonuçlar. 21. Yüzyıl Eğitim Yöneticilerinin Yetiștirilmesi Sempozyomu, Ankara Üniversitesi Eğitim Bilimleri Fakültesi Yayınları, 191, 239-253.

[21] Oklay, E. (2016). Okul yöneticilerinin liderlik becerileri ve yeterlik alanları. Aypay, A. (Ed.), Türkiye'de eğitim yöneticiliği ve maarif müfettişliği: seçme, atama ve yetiştirme (87-111). Ankara: Pegem Akademi.

[22] Erginer, A. ve Köse, M.F. (2012). Okul yöneticilerinin yöneticiliği tercih ve brrakma nedenlerine ilişkin nitel bir çalışma. e-Journal of New World Sciences Academy NWSA-Qualitative Studies. 7, (4), 14-28. 
[23] Aydın, A. (2015). Eğitim politikası. Ankara: PegemA Yayıncilik.

[24] Kayıkçı, K. (2001). Yönetici yetiştirme sorunu. Milli Eğitim Dergisi. 150, 28-32.

[25] Arabacı, İ. B., Şanlı, Ö. ve Altun, M. (2015). Okul yöneticilerinin yetiştirilme ve atama yöntemlerine ilişkin sendika temsilcilerinin, maarif müfettişlerinin ve okul yöneticilerinin viewsinin değerlendirilmesi. Mustafa Kemal Üniversitesi Sosyal Bilimler Enstitüsü Dergisi. 12 (31), 166-186.

[26] Yıldırım, A. ve Şimşek, H. (2013). Sosyal bilimlerde nitel araștırma yöntemleri. Ankara: Seçkin Yayıncılık.

[27] Patton, M. Q. ( 2015). Qualitative Research and Evaluation Methods. 4th edition, SAGE Publications.

[28] Aktepe, V. (2014). Okul yöneticilerinin seçme ve yetiştirme uygulamalarına yönelik öğretmen ve yönetici görüşleri. Turkish Studies - International Periodical for the Languages, Literature and History of Turkish or Turkic. 9 (2), 89-105.

[29] Özmen, F. ve Kömürlü, F. (2010). Eğitim örgütlerine yönetici seçme ve atamada yaşanan sorunlar ve yönetici görüşleri temelinde çözüm önerileri. Sosyal ve Beşeri Bilimler Dergisi. 2 (1), 25-33.
[30] Türkmenoğlu, G. ve Tuncer, B. (2015). Okul yöneticilerinin göreve geliş biçimlerinin okul kültürüne yansımaları. Mersin Üniversitesi Eğitim Fakültesi Dergisi. 11, (2), 526-549.

[31] Gülșen, C. ve Dayığlu, S. (2015). Milli eğitim bakanlığına bağlı okullara yönetici atama kriterleri konusunda okul yöneticilerinin görüşleri. International Journal of Social Sciences and Education Research. 1 (4), 1487-1499.

[32] Argon, T., Yıldırım, F.A. ve Kurt A. (2014). Yöneticilerin sahip olduğu güç stilleri ve iş çevrelerine uyuma ilişkin öğretmen görüşleri. Bartın Üniversitesi Eğitim Fakültesi Dergisi. 3 (2), 26 - 48.

[33] Ada, S., Dilekmen, M., Alver, B., ve Seçer, İ. (2010). İlk ve ortaöğretim okul yöneticilerinin problem çözme becerilerinin çeșitli değişkenler açısından incelenmesi. Kuram ve Uygulamada Eğitim Yönetimi. 16 (2), 153-166.

[34] Şekerci, M. ve Aypay, A. (2009). İlköğretim okulu yöneticilerinin yönetim becerileri ile grup etkililiği arasındaki ilișki. Kuram ve Uygulamada Eğitim Yönetimi. 15 (57), 133-160.

[35] Gurr, D. (2015), A Model of Successful School Leadership from the International Successful School Principalship Project, Societies, 5, (1), 136. 